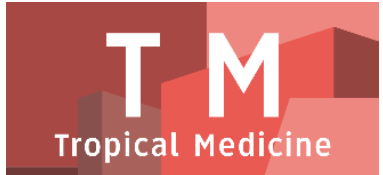

PAPER - OPEN ACCESS

\title{
Skrining Mekanisme Kerja Daun Malaka (Phyllanthus emblica L.) Sebagai Antidiabetes
}

\author{
Author \\ DOI \\ : Novi Irwan Fauzi \\ Electronic ISSN \\ : 10.32734/tm.v1i3.271 \\ Print ISSN \\ : 2623-0542 \\ : 2623-0550
}

Volume 1 Issue 3 - 2018 TALENTA Conference Series: Tropical Medicine (TM)

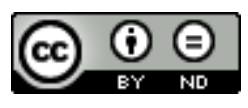

This work is licensed under a Creative Commons Attribution-NoDerivatives 4.0 International License.

Published under licence by TALENTA Publisher, Universitas Sumatera Utara
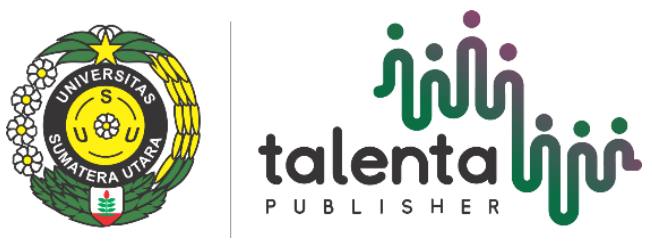


\title{
indi talentalịi TALENTA Conference Series \\ P U B L I S H E R Available online at https://talentaconfseries.usu.ac.id \\ Skrining Mekanisme Kerja Daun Malaka (Phyllanthus emblica L.) Sebagai Antidiabetes
}

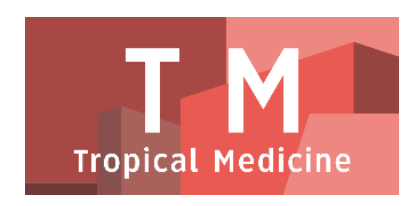

\author{
Novi Irwan Fauzi ${ }^{\mathrm{a}^{*}}$, Seno Aulia Ardiansyaha ${ }^{\mathrm{a}}$, Saeful Hidayat ${ }^{\mathrm{a}}$ \\ ${ }^{a}$ Sekolah Tinggi Farmasi Indonesia, Bandung, Indonesia 40266
}

Email*: noviirwan@stfi.ac.id

\begin{abstract}
Abstrak
Daun malaka (Phyllanthus emblica L.) mempunyai potensi digunakan sebagai alternatif obat antidiabetes. Daun malaka menunjukkan efek hipoglikemia pada tikus yang diinduksi aloksan. Namun, mekanisme kerjanya belum diketahui pasti. Penelitian ini dilakukan dalam rangka skrining mekanisme kerja daun malaka sebagai antidiabetes. Skrining mekanisme kerja dilakukan terhadap fraksi air daun malaka melalui uji aktivitas inhibisi enzim $\alpha$-glukosidase serta $\alpha$-amilase secara in vitro dan pengujian aktivitas insulin-sensitizer terhadap ekstrak daun malaka dengan metode tes toleransi insulin secara in vivo. Fraksi air daun malaka menunjukkan aktivitas inhibisi terhadap enzim $\alpha$-glukosidase serta $\alpha$-amilase dengan nilai $I C_{50}$ (Inhibitor Concentration 50) pada kedua enzim tersebut berturut-turut adalah $0,87 \%$ dan $8,64 \%$ b/v. Pada uji aktivitas insulin sensitizer, pemberian ekstrak daun malaka dapat meningkatkan sensitivitas insulin pada tikus diabet dengan kondisi

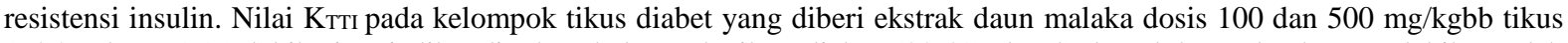
$(74,89$ dan 75,57$)$ lebih tinggi dibandingkan kelompok tikus diabet $(38,41)$ dan kadar glukosa darah yang lebih rendah selama interval waktu pengukuran. Daun malaka telah diketahui mampu meningkatkan sekresi insulin dan pada penelitian ini menunjukkan aktivitas inhibisi enzim $\alpha$-glukosidase serta $\alpha$-amilase secara in vitro dan menunjukkan aktivitas insulinsensitizer pada tikus diabet dengan kondisi resistensi insulin.
\end{abstract}

Kata Kunci: Daun Malaka, insulin sensitizer, inhibitor $\alpha$-glukosidase, inhibitor $\alpha$-amilase

\begin{abstract}
Amla leaves (Phyllanthus emblica L.) have potential to be used as an alternative antidiabetic drugs. It showed hypoglycemic effect in alloxan-induced diabetic rats. However, the mechanism of action is not known. This research was conducted in order to screen the mechanism of action of amla leaf as an antidiabetic. Screening mechanism of action was performed through inhibition of $\alpha$-glucosidase and $\alpha$-amylase enzyme activity by in vitro and insulin-sensitizer activity in vivo by tolerance test method. Amla leaf water fraction showed activity of inhibition to enzyme $\alpha$-glucosidase and $\alpha$-amylase with IC50 value (Inhibitor Concentration 50) in both enzymes were $0.87 \%$ and $8.64 \% \mathrm{w} / \mathrm{v}$ respectively. In insulin sensitizer activity test, giving leaf of amla extract can increase insulin sensitivity in diabetic rat with insulin resistance condition. The

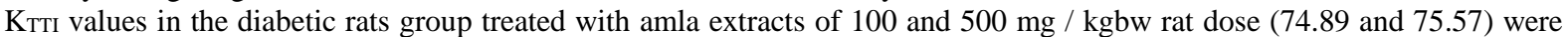
higher than in the diabetic rats group (38.41) and lower blood glucose levels during the interval time measurement. Amla leaves has been known to increase insulin secretion and in this research showed inhibition of $\alpha$-glucosidase enzyme activity and $\alpha$-amylase in vitro and showed insulin-sensitizer activity in diabetic Rats with insulin resistance condition.
\end{abstract}

Keywords: Amla leaf, insulin sensitizer, $\alpha$-glucosidase inhibitor, $\alpha$-amylase inhibitor

\section{Pendahuluan}

Tanaman Malaka (Phyllanthus emblica L.) dikenal dibeberapa daerah Indonesia dengan sebutan kimalaka (Melayu), balaka (Minangkabau), malaka (Sunda dan Betawi), kemloko (Jawa), malakah (Madura). Dalam bahasa Inggris tanaman ini disebut sebagai indian gooseberry, amlaatau myrobalan [1] [2]. Secara empiris dalam pengobatan Ayurveda, malaka biasa digunakan dalam pengobatan diare, flu, demam, diuretik, pencahar, dan sebagai tonik rambut [3].

Senyawa fitokimia yang terkandung di dalam ekstrak etanol buah dan daun malaka tidak jauh berbeda. Senyawa-senyawa tersebut diantaranya alkaloid, minyak atsiri, gliseroid, karbohidrat, fenol, tanin, lignin, saponin, flavonoid,dan terpenoid. Akan tetapi, pada daun tidak terdapat senyawa terpenoid [4]. Buah malaka menunjukkan efek hipoglikemia pada tikus jantan Long Evans melalui penghambatan asupan glukosa ke dalam darah [5]. Juga, ekstrak air buah malaka pada dosis $200 \mathrm{mg} / \mathrm{kgbb}$ menunjukkan efek hipoglikemia pada tikus yang diinduksi diabetes dengan menggunakan aloksan [6]. 
Melalui pendekatan fitokimia daun malaka mempunyai potensi menunjukkan efek yang sama seperti pada buah. Berdasarkan hasil penelitian Sutriana dkk. (2011), ekstrak daun malaka dosis $400 \mathrm{mg} / \mathrm{kgbb}$ menunjukkan efek hipoglikemia pada tikus yang diinduksi diabetes menggunakan aloksan $120 \mathrm{mg} / \mathrm{kgbb}$. Efek tersebut kemungkinan terjadi salah satunya karena terstimulasinya sel $\beta$-pankreas untuk mensekresi insulin. Oleh karena itu, daun malaka dapat disimpulkan mempunyai aktivitas insulin secretogogeus [7].

Penelitian ini dilakukan dalam rangka skrining mekanisme kerja daun malaka sebagai antidiabetes. Skrining mekanisme kerja daun malaka dapat dilakukan melalui pendekatan terhadap modalitas obat konvensional yang ada saat ini. Secara keseluruhan dapat disimpulkan bahwa strategi pengendalian kadar glukosa darah dilakukan melalui blokade/menghambat absorpsi glukosa ke dalam darah (inhibisi aktivitas enzim $\alpha$-glukosidase), memperbanyak asupan glukosa ke dalam jaringan (Insulin secretogogeus dan Insulin Sensitizer) dan memperbanyak ekskresi glukosa melalui urin (Sodium Glucose Linked Transporter 2).

\section{Bahan dan Metode}

\subsection{Bahan}

Daun malaka diperoleh dari salah satu perkebunan di daerah Cianjur, Jawa Barat. Pada uji aktivitas inhibisi enzim $\alpha$-glukosidase dan $\alpha$-amilase, bahan yang digunakan adalah enzim $\alpha$-glukosidase dan $\alpha$-amilase (Sigma ${ }^{\circledR}$ ), p-nitrophenil- $\alpha$-D-glucopyranoside (p-NPG) $\left(\right.$ Sigma $\left.^{\circledR}\right)$, asam 3,5-dinitrosalisilat (DNS)(Sigma ${ }^{\circledR}$ ), amilum $1 \%$, dan akarbosa $\left(\right.$ Glucobay ${ }^{\circledR}$ ). Pada uji aktivitas insulin sensitizer, hewan coba yang digunakan adalah tikus galur Wistar dengan bobot 150 - 300 gram, formula diet tinggi lemak, Metformin digunakan sebagai pembanding, diperoleh dari PT. Narda Tita. Dan, Insulin $\left(\right.$ Novomix $\left.^{\circledR}\right)$ digunakan pada uji tes toleransi insulin. Alat yang digunakan pada penelitian ini adalah spektrofotometer Uv-Vis(Shimadzu UV-1800), Blood Glucose Test Meter (Easy Trouch®)

\subsection{Metode penelitian}

Tanaman malaka dideterminasi di Laboratorium Taksonomi Tumbuhan, Departeman Biologi FMIPA Universitas Padjadjaran. Simplisia daun malaka diekstraksi menggunakan pelarut etanol 96\% dengan metode maserasi. Ekstrak etanol daun malaka difraksinasi menggunakan metode ekstraksi cair-cair. Karakterisasi dilakukan terhadap simplisia dan skrining fitokimia dilakukan terhadap simplisia, ekstrak serta fraksi air daun malaka. Uji aktivitas inhibisi enzim $\alpha$-glukosidase dilakukan pada lima konsentrasi fraksi air daun malaka yaitu $0,4 \% ; 0,6 \% ; 0,8 \% ; 1 \%$; dan 1,2\%. Sebanyak $24 \mu \mathrm{l}$ enzim $\alpha$-glukosidase ditambahkan ke dalam wadah yang berisi $200 \mu \mathrm{l}$ dapar posfat pH 6,8 dan $40 \mu \mathrm{l}$ p-NPG. Kemudian ditambahkan fraksi air daun malaka untuk masing-masing konsentrasi, diinkubasi pada suhu $37^{\circ} \mathrm{C}$ selama 20 menit. Reaksi dihentikan dengan penambahan $200 \mu \mathrm{l}$ natrium karbonat $200 \mathrm{mM}$. p-nitrofenol sebagai hasil reaksi diukur pada $\lambda 400 \mathrm{~nm}$. Pada uji aktivitas inhibisi enzim $\alpha$-amilase, dilakukan pengujian pada lima variasi konsentrasi fraksi air daun malaka yaitu 7,3\%; $7,6 \% ; 8,0 \% ; 8,3 \%$; dan $8,6 \%$. Sebanyak $80 \mu 1$ enzim $\alpha$-amilase ditambahkan ke dalam wadah yang berisi $160 \mu 1$ dapar posfat pH 6,8 dan $80 \mu \mathrm{l}$ amilum $1 \%$. Kemudian ditambahkan fraksi air daun malaka untuk masing-masing konsentrasi, diinkubasi pada suhu $37^{\circ} \mathrm{C}$ selama 15 menit. Reaksi dihentikan melalui pemanasan pada suhu $85^{\circ} \mathrm{C}$ dan penambahan DNS. Maltosa sebagai hasil reaksi diukur pada $\lambda 500 \mathrm{~nm}$.

Persentase inhibisi aktivitas enzim $\alpha$-glukosidase dan $\alpha$-amilase ditentukan menggunakan persamaan berikut:

$$
\% \text { inhibisi }=100-\left[\frac{\text { Absorbansi sampel }}{\text { Absorbansi kontrol }(-)}\right] \times 100 \%
$$

dan nilai IC50 diperoleh dari persamaan regresi liner.

Pada uji aktivitas insulin sensitizer, secara acak 15 ekor tikus jantan galur wistar dibagi menjadi kelompok tikus normal, tikus diabet, kontrol obat (metformin $45 \mathrm{mg} / \mathrm{kgbb}$ ) dan dua kelompok tikus yang diberi ekstrak daun malaka berturut-turut dosis 100 dan $500 \mathrm{mg} / \mathrm{kgbb}$. Formula diet tinggi lemak diberikan per oral selama 21 hari untuk menginduksi diabetes dengan kondisi resistensi insulin. Pada hari ke 22 setelah dipuasakan selama 18 jam, masing-masing kelompok diberikan perlakuan sesuai kelompok perlakuannya. Kemudian, kadar glukosa darah diukur setelah pemberian insulin $10 \mathrm{U} / 0,1 \mathrm{ml}$ intra peritonial menggunakan blood glucose test metersetiap 30 menit selama 2 jam.Sensitivitas insulin dianalisis dari perbandingan nilai konstanta tes toleransi insulin ( $\mathrm{K}_{\text {TTI }}$ ) yang diperoleh dari hasil kali koefisien regresi (r) dengan 100. Koefisien regresi diperoleh dari persamaan regresi linier antara waktu dan kadar glukosa darah. Nilai $\mathrm{K}_{\text {TTI }}$ yang tinggi menunjukkan sensitivitas terhadap insulin.

\section{Hasil dan Pembahasan}

Berdasarkan hasil determinasi, bahan uji yang diperoleh dapat dipastikan adalah tanaman malaka dengan nama ilmiah Phyllanthus emblica L. Kualitas simplisia daun malaka yang digunakan ditetapkan melalui karakterisasi simplisia. Hasilnya ditunjukkan pada tabel berikut: 
Tabel 1. Hasil Karakterisasi Simplisia Daun Malaka

\begin{tabular}{lcc}
\hline \multicolumn{1}{c}{ Karakterisasi } & Hasil (\%) \\
\hline Kadar Abu Total & 3,5 & 0,025 \\
Kadar Abu Tidak Larut Asam & 3 & 29 \\
Kadar Abu Tidak Larut Air & 27 \\
Kadar Sari Larut Etanol & 7,76 \\
Kadar Sari Larut Air & 2 \\
Kadar Susut Pengeringan & 2 \\
Kadar Air & & \\
\hline
\end{tabular}

Skrining fitokimia dilakukan terhadap simplisia, ekstrak dan fraksi air daun malaka untuk mengetahui kandungan golongan senyawa metabolit sekunder sebagai upaya langkah awal dalam karakterisasi senyawa yang bertanggung jawab terhadap aktivitas farmakologi. Hasilnya disajikan pada tabel berikut:

Tabel 2. Hasil Skrining Fitokimia Simplisia, Ekstrak dan Fraksi Air Daun Malaka

\begin{tabular}{lccc}
\hline & Golongan Senyawa & Simplisia & Ekstrak \\
\hline Alkaloid & + & + & + \\
Flavinoid & + & + & + \\
Tanin & + & + & + \\
Fenolat & + & + & + \\
Saponin & + & + & + \\
Kuinon & + & + \\
Monoterpen dan & + & + \\
Seskuiterpen & & + \\
Steroid dan & & + \\
Triterpenoid & & + \\
\hline
\end{tabular}

3.1 Hasil Uji Aktivitas Inhibisi Enzim $\alpha$-Glukosidase dan $\alpha$-Amilase

Salah satu upaya menurunkan kadar glukosa darah adalah menghambat absorpsi glukosa dari saluran pencernaan ke dalam darah ketika makan. Akarbosa merupakan salah satu obat konvensional dengan cara kerja tersebut melalui penghambatan aktivitas enzim $\alpha$-glukosidase dan $\alpha$-amilase dalam katabolisis karbohidrat. Melalui pendekatan tersebut, kajian mekanisme kerja daun malaka sebagai antidiabetes dilakukan dengan uji aktivitas inhibisi enzim $\alpha$-glukosidase dan $\alpha$-amilase secara in vitro dengan pembanding akarbosa.

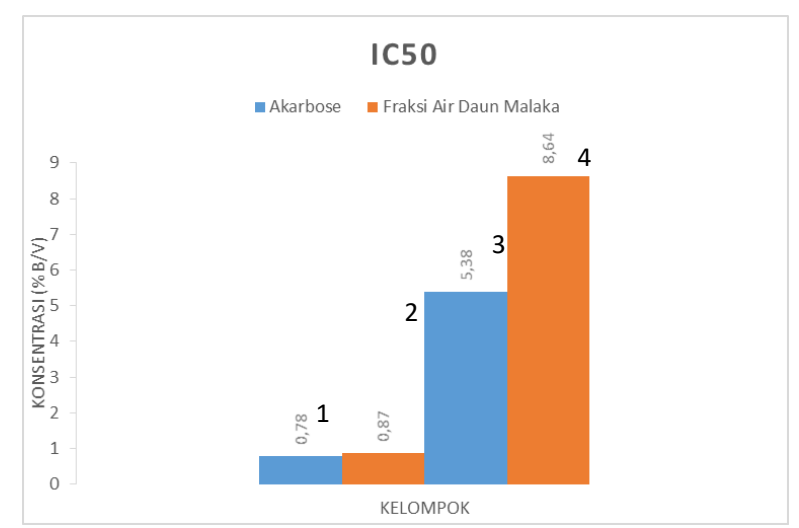

Gambar 1. Grafik Perbandingan Nilai IC50 Fraksi Air Daun Malaka dengan Akarbosa pada Enzim $\alpha$-Glukosidase dan $\alpha$-Amilase (Ket: Bar 1 dan 2 Nilai IC $_{50}$ terhadap enzim $\alpha$-Glukosidase, Bar 3 dan 4 Nilai IC $_{50}$ terhadap enzim $\alpha$-Amilase)

Hasil pengujian menunjukkan bahwa daun malaka dapat menghambat aktivitas enzim $\alpha$-glukosidase dan $\alpha$ amilase. Nilai $\mathrm{IC}_{50}$ pada kedua enzim tersebut berturut-turut adalah $0,87 \%$ dan $8,64 \% \mathrm{~b} / \mathrm{v}$. Aktivitasnya lebih dominan terhadap enzim $\alpha$-glukosidase dibandingkan $\alpha$-amilase. Potensi inhibisi pada kedua enzim tersebut masih lebih rendah dibandingkan akarbose sebagai obat pembanding.

\subsection{Hasil Uji Aktivitas Insulin-Sensitizer}

Metformin dan golongan Tiazolidindion merupakan obat diabetes melitus dengan mekanisme kerja meningkatkan sensitivitas insulin (insulin sensitizer). Melalui pendekatan tersebut, uji aktivitas insulin senitizer daun malaka secara in vivo dilakukan dengan metode tes toleransi insulin untuk mengkaji mekanisme kerjanya sebagai antidiabetes.

Pada uji aktivitas insulin-sensitizer, bahan uji yang digunakan adalah ekstrak etanol daun malaka. Analisis aktivitas dinilai dari konstanta tes toleransi insulin $\left(\mathrm{K}_{\mathrm{TTI}}\right)$. 
Tabel 3. Perbandingan Rata-Rata Kadar Glukosa Darah Puasa antar Kelompok Perlakuan

\begin{tabular}{|c|c|c|c|c|c|}
\hline \multirow{2}{*}{ Kelompok } & \multicolumn{5}{|c|}{$\begin{array}{l}\text { Rata-Rata Kadar Glukosa Darah Puasa Tikus (mg/dL) } \\
\text { pada Menit ke- }\end{array}$} \\
\hline & T0 & $\mathrm{T} 30$ & T60 & T90 & $\mathrm{T} 120$ \\
\hline Tikus Normal & 81 & 79 & 76 & 76 & 79 \\
\hline $\begin{array}{l}\text { Tikus Model Diabet } \\
\text { Dengan Kondisi Resistensi Insulin }\end{array}$ & 187 & 183 & 188 & 184 & 190 \\
\hline Kontrol Obat (Metformin $45 \mathrm{mg} / \mathrm{kgbb}$ ) & 153 & 82 & 74 & 75 & 72 \\
\hline EDM dosis $100 \mathrm{mg} / \mathrm{kgbb}$ & 166 & 47 & 61 & 56 & 37 \\
\hline EDM dosis $500 \mathrm{mg} / \mathrm{kgbb}$ & 147 & 43 & 41 & 37 & 34 \\
\hline \multicolumn{6}{|c|}{$\begin{array}{l}\text { Berdasarkan hasil pada tabel } 3 \text {, kadar glukosa darah puasa kelompok tikus diabet y } \\
\text { malaka pada dosis } 100 \text { dan } 500 \mathrm{mg} / \mathrm{kgbb} \text { lebih rendah dibandingkan kelompok tikus dia } \\
\text { diprediksikan bahwa pada kelompok tikus diabet yang diberi ekstrak daun malaka memiliki } \\
\text { lebih tinggi. Hal tersebut dikonfirmasi melalui nilai } \mathrm{K}_{\mathrm{TTI}} \text { untuk membuktikan pemberian el } \\
\text { kedua dosis dapat meningkatkan sensitivitas insulin. } \\
\text { Tabel 4. Nilai Konstanta Tes Toleransi Insulin }\left(\mathrm{K}_{\mathrm{TTI}}\right) \text { antar Kelompok Perlakuan }\end{array}$} \\
\hline Kelompok & & \multicolumn{4}{|c|}{$\begin{array}{r}\mathrm{K}_{\mathrm{TTI}} \\
\end{array}$} \\
\hline Tikus Normal & & \multicolumn{4}{|c|}{51,04} \\
\hline $\begin{array}{l}\text { Tikus Model Diabet } \\
\text { Dengan Kondisi Resistensi Insulin }\end{array}$ & & \multicolumn{4}{|c|}{38,41} \\
\hline Kontrol Obat (Metformin $45 \mathrm{mg} / \mathrm{kgbb}$ ) & & \multicolumn{4}{|c|}{78,07} \\
\hline EDM dosis $100 \mathrm{mg} / \mathrm{kgbb}$ & & \multicolumn{4}{|c|}{74,89} \\
\hline EDM dosis $500 \mathrm{mg} / \mathrm{kgbb}$ & & \multicolumn{4}{|c|}{75,57} \\
\hline
\end{tabular}

Pada tabel 4, nilai $\mathrm{K}_{\text {TTI }}$ kelompok tikus diabet yang diberi ekstrak lebih besar dibandingkan kelompok tikus diabet. Nilai $\mathrm{K}_{\text {TTI }}$ yang lebih tinggi menunjukkan tingginya sensitivitas insulin. Hasilnya menegaskan bahwa ekstrak daun malaka dapat meningkatkan sensitivitas insulin pada tikus diabet dengan kondisi resistensi insulin.

\section{Kesimpulan}

Daun malaka mampu meningkatkan sekresi insulin pada tikus yang diinduksi aloksan, dapat menghambat aktivitas enzim $\alpha$-Glukosidase dan $\alpha$-Amilase secara in vitro yang aktivitasnya lebih dominan terhadap enzim $\alpha$ Glukosidase dan daun malaka mampu meningkatkan sensitivitas insulin pada tikus dengan kondisi resistensi insulin.

\section{Ucapan Terima Kasih}

Penulis berterimakasih kepada Seva Melisa dan Rifa Fauziah yang telah membantu dalam pelaksanaan penelitian.

\section{Daftar Pustaka}

[1] Holthoon, L, 2011. Phytochemistry, Traditional Uses and Cancer Chemopreventive Activity of Amla (Phyllanthus emblica).Journal of Applied Pharmaceutical Science Medicinal and Plant, 12(1), 388 - 389.

[2] Heyne, K. 1987. Tumbuhan Berguna Indonesia, Vol 2 (diterjemahkan oleh: Badan Litbang Kehutanan), Yayasan Sarana Wana Jaya,Jakarta, hal. 1137.

[3] Dasaroju, S dan Gottimukkala, KM, 2014. Current Trend in the Research of Emblica officinalis (Amla): A Pharmacological Perspective, International Journal Pharmaceutical Sciences, 24(3), 150 - 159.

[4] Dhale, DA dan Mogle UP, 2011. Phytochemical Screening and Antibacterial Activity of Phyllanthus emblica (L.). Journal Science Research Reporter, 1(3), 138 - 142.

[5] Sultana, Z, Jami, SI, Ali, E, Begum, M, Haque, Mominul, 2014. Investigation of Antidiabetic Effect of Ethanolic Extract of Phyllanthus emblica Linn. Fruits in Experimental Animal Models. Scientific Research (Pharmacology \& Pharmacy Journal), 5(1), 11 - 18.

[6] Qureshi, SA, Asad W dan Sultana, V, 2009. The Effect of Phyllanthus emblica Linn on Type-II Diabetes, Triglycerides and Liver Specific Enzyme. Pakistan Journal of Nutrition, 8(2), 125 - 128. 
[7] Sutriana A, Armansyah T, Rusli T, Asmilia N, Syuti A, 2011. Ekstrak Etanol Daun Malaka (Phyllanthus emblica L.) Sebagai Anti Diabetes pada Tikus Putih (Rattus novergicus) yang Diinduksi Aloksan. Media Kedokteran Hewan (Vet. Med. J, 27(2), 83 - 87. 